
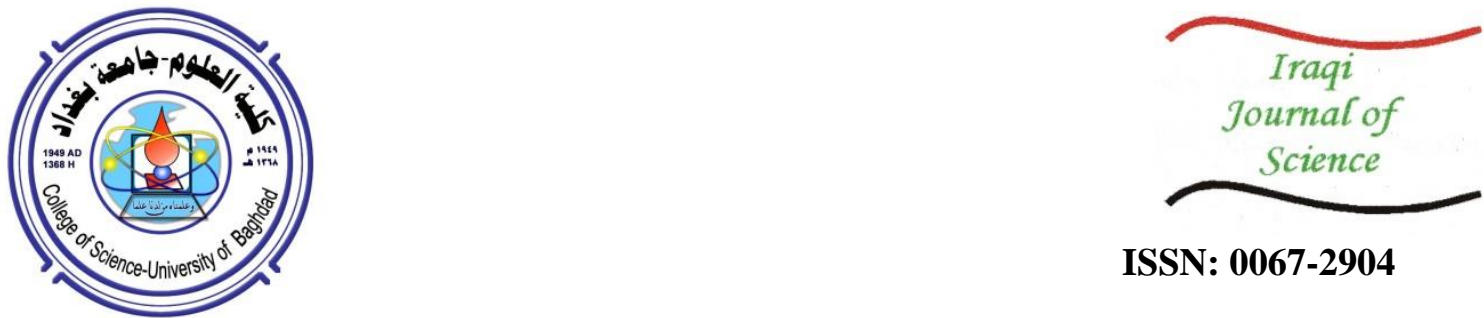

ISSN: 0067-2904

\title{
Characterization of Calcinated Ni-Cu Ferrite Nanoparticles Synthesized by Citrate-gel Auto combustion Technique
}

\author{
Ibrahim F. Waheed ${ }^{1}$, Thuraya Yarb Sabri ${ }^{2}$, Najat A. Dahham ${ }^{* 2}$, Faten Haithum Mulud ${ }^{2}$ \\ ${ }^{1}$ Department of Chemistry, College of Science, University of Tikrit, Tikrit, Iraq \\ ${ }^{2}$ Department of Physics, College of Science, University of Tikrit, Tikrit, Iraq
}

Received: $7 / 3 / 2020 \quad$ Accepted: $19 / 5 / 2020$

\begin{abstract}
Citrate-gel auto combustion technique was used to synthesize nickel-copper mixed ferrite nanoparticles $\mathrm{Ni}_{\mathrm{x}} \mathrm{Cu}_{1-\mathrm{x}} \mathrm{Fe}_{2} \mathrm{O}_{4}(\mathrm{x}=0.0,0.4,1.0)$ with different calcinating temperatures $\left(200,450,650\right.$ and $\left.850{ }^{\circ} \mathrm{C}\right)$. Structural, morphological, magnetic, and electrical properties were studied using X-ray diffraction (XRD), transmission electron microscopy (TEM), field emission scanning electron microscopy (FE-SEM), Fourier transform infrared spectroscopy (FTIR), vibrating sample magnetometer (VSM), and LCR meter in order to determine significant influences of $\mathrm{Cu}^{2+}$ cations content in nickel ferrite. The XRD patterns showed that all compositions had cubic spinels, except $\mathrm{CuFe}_{2} \mathrm{O}_{4}$ samples. The system structure in $\mathrm{Cu}$-ferrite was deformed at $650{ }^{\circ} \mathrm{C}$ from a cubic to a tetragonal system with a secondary phase $\mathrm{CuO}$. Lattice constant was decreased with increasing $\mathrm{Cu}^{2+}$ cations substitution in Ni-ferrites, while crystalline volume was increased. With the help of Debye-Scherrer`s equation using XRD data, we found that the crystallite size at 850 ${ }^{\circ} \mathrm{C}$ is lying in the range from 38.70 to $48.00 \mathrm{~nm}$. The FTIR spectrum of samples under investigation showed two significant absorption bands, which refer to the formation of a single-phase cubic spinel. The magnetization test revealed a soft ferromagnetic behavior for all the compositions sintered at $850{ }^{\circ} \mathrm{C}$. The saturation magnetization (Ms) was decreased with the substitution by $\mathrm{Cu}^{2+}$ cations, while remnant magnetization $(\mathrm{Mr})$ and coercivity $(\mathrm{Hc})$ were increased in $\mathrm{Cu}$-ferrite. The highest Ms value was $42.25 \mathrm{emu} . \mathrm{g}^{-1}$ for Ni-ferrite, while the highest $\mathrm{Hc}$ value was $517.16 \mathrm{O}_{\mathrm{e}}$ for $\mathrm{Cu}$-ferrite. The electrical measurement of samples showed an increase in the real dielectric constant and AC conductivity at a frequency range of $20 \mathrm{~Hz}$ $3 \mathrm{MHz}$ with the addition of copper cations.
\end{abstract}

Keywords: Nickel-copper ferrite, Magnetic properties, dielectric properties

$$
\begin{aligned}
& \text { تشخيص الجسيمات النانويـة لفرايت Cu-Ni المحضرة بتقنية الاحترلق التلقائي لجل السترات }
\end{aligned}
$$

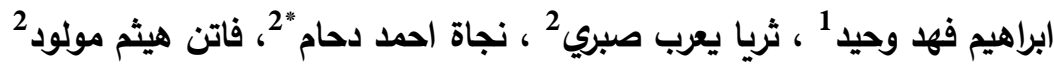

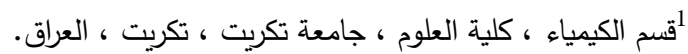

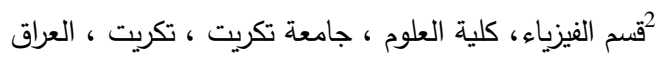

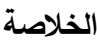

$$
\begin{aligned}
& \text { تم استخدام تقنية الاحتراق التلقائي لسيترات- جل لتصنيع جسيمات الفرايت النانوية المختلطة من النيكل } \\
& \text { والنحاس x } \\
& \text { 200,450,650,850)CC تمت دراسة الخواص التركيبية والمورفولوجية والمغناطيسية والكهربائية باستخدام }
\end{aligned}
$$

*Email: imaofs76@yahoo.com 


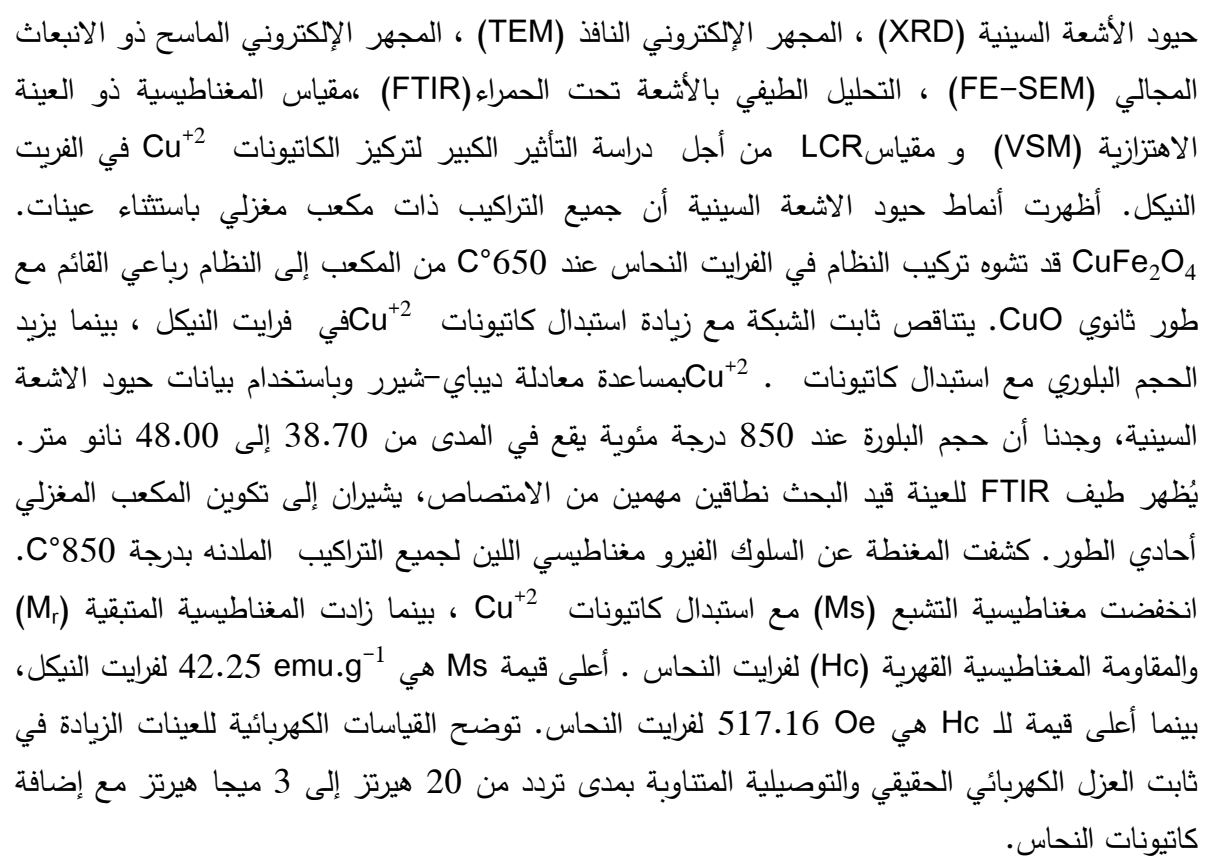

\section{Introduction}

In recent years, the ferrites family has gained a great importance among researchers, as these materials have been greatly desired in various electrical industries. They are electrically insulated and accompanied by high resistance, leading to their employment in changing magnetic fields because their loss of eddy currents is very slight. This feature made such materials more widely used in the applications of microwave and magnetic fluids [1], recording disks, transformer molds, gas sensors, and moisture sensors [2,3]. The general formula for spinel ferrites is $\mathrm{MFe}_{2} \mathrm{O}_{4}$, where $\mathrm{M}$ is a metallic divalent ion (e.g., $\mathrm{Cu}, \mathrm{Fe}, \mathrm{Cd}, \mathrm{Ni}, \mathrm{Zn}$, etc.) [4]. Among the most famous ferrites are $\mathrm{CuFe}_{2} \mathrm{O}_{4}$ and $\mathrm{NiFe}_{2} \mathrm{O}_{4}$, due to their inverse spinel structure. They have ferromagnetic behavior and wide device applications. The substitution of copper in nickel ferrite enhances the dielectric properties. Besides, it reduces the magnetic properties of nickel ferrite, which is useful in many device applications [5]. $\mathrm{CuFe}_{2} \mathrm{O}_{4}$ and $\mathrm{NiFe}_{2} \mathrm{O}_{4}$ were prepared by various methods, such as the ceramic method [6], electrodeposition method [7], hydrothermal reaction [8], oxidation precipitation [9], sol-gel method [10], and electrochemical method [11]. Among the best methods for preparing ferrite compounds is the self-combustion method for the gel, because it is easy to prepare, does not need high temperature, the interacting elements and the granular size of the powder nanoparticles can be controlled, and free from impurities [12]. The aim of the present work is to understand the role of $\mathrm{Cu}^{2+}$ cations in controlling the dielectric and magnetic behavior of Ni-ferrite. Therefore, a series of $\mathrm{Ni}_{\mathrm{x}} \mathrm{Cu}_{1-\mathrm{x}} \mathrm{Fe}_{2} \mathrm{O}_{4}(\mathrm{x}=$ $0.0,0.4,1.0)$ spinel ferrite samples were prepared and the consequent changes in several parameters, such as lattice constant, crystalline volume, density, saturation magnetization, dielectric permittivity, and dielectric loss tangent, were discussed in this paper. Furthermore, we investigated the effect of calcination temperature on the parameters above.

\section{Experimental Part}

\subsection{Synthesis of $\mathrm{Ni}_{\mathrm{x}} \mathrm{Cu}_{1-\mathrm{x}} \mathrm{Fe}_{2} \mathrm{O}_{4}$ nanoparticles}

The spinel samples of $\mathrm{Ni}_{\mathrm{x}} \mathrm{Cu}_{1-\mathrm{x}} \mathrm{Fe}_{2} \mathrm{O}_{4}$ were prepared with values of $\mathrm{x}=0.0,0.4,1.0$ using the citrate-gel auto combustion technique. Iron nitrate $\left(\mathrm{Fe}\left(\mathrm{NO}_{3}\right)_{3} \cdot 9 \mathrm{H}_{2} \mathrm{O}\right)$, copper nitrate $(\mathrm{Cu}$ $\left.\left(\mathrm{NO}_{3}\right)_{2} \cdot 3 \mathrm{H}_{2} \mathrm{O}\right)$, nickel nitrate $\left(\mathrm{Ni}\left(\mathrm{NO}_{3}\right)_{2} .6 \mathrm{H}_{2} \mathrm{O}\right)$, Citric acid $\left(\mathrm{C}_{6} \mathrm{H}_{8} \mathrm{O}_{7} \mathrm{H}_{2} \mathrm{O}\right)$, and ammonia $\left(\mathrm{NH}_{3} \mathrm{OH}\right)$ were used as raw materials for preparing the compounds of $\mathrm{Ni}_{x} \mathrm{Cu}_{1-x} \mathrm{Fe}_{2} \mathrm{O}_{4}$ nanoparticles. A stoichiometric ratio of nickel nitrate $(1.163 \mathrm{~g})$ and ferric nitrate $(3.232 \mathrm{~g})$ was mixed in $50 \mathrm{ml}$ deionized water. The molar ratio of nickel nitrate and ferric nitrate was 1:2. Citric acid was added as a fuel in the metal nitrate with a ratio of 3:1 under vigorous stirring conditions. The ferrite samples were successfully prepared by doping of $\mathrm{Cu}^{2+}$ with different molar ratios $\left(\mathrm{Ni}_{\mathrm{x}} \mathrm{Cu}_{1-\mathrm{x}} \mathrm{Fe}_{2} \mathrm{O}_{4}, \mathrm{x}=0.0,0.4,1.0\right)$ to nickel ferrite. Copper nitrate amounts that were added to nickel nitrate solution were $1.182 \mathrm{~g}$ and $0.177 \mathrm{~g}$ for molar ratios of 0.0 and 0.4 , respectively. The $\mathrm{pH}$ value of the solution mixture was maintained at 8 by ammonia solution. The mixing process was continued to ensure complete mixing of 
the solution and a good distribution of the components at room temperature. After that, the temperature was gradually raised and then fixed at $90^{\circ} \mathrm{C}$ with the stirring process continuing until the gel form was reached. After around 10 min the gel began to burn out to form a dry gel (Xerogel). The final burnt powders were then thermally calcinated at $200,450,650$, and $850^{\circ} \mathrm{C}$ for $3 \mathrm{~h}$ to obtain wellcrystallized $\mathrm{Ni}_{\mathrm{x}} \mathrm{Cu}_{1-\mathrm{x}} \mathrm{Fe}_{2} \mathrm{O}_{4}$.

\subsection{Materials characterization}

The X-ray diffraction patterns of the samples were identified using X-ray Diffractometer (XRD6000 from Shimadzu, Japan) using $\mathrm{Cu} \mathrm{K} \alpha$ radiation $(\lambda=1.5406 \AA)$, with $(2 \theta)=10^{\circ}-80^{\circ}$ in steps of 5 $\mathrm{deg} / \mathrm{s}$. Spectra of the powders were recorded using FTIR spectrometer (FTIR 8400S from Shimadzu, Japan) in the wave number range of $400-3500 \mathrm{~cm}^{-1}$ to confirm the spinel structure of the samples. The surface morphology was analyzed through the use of FE-SEM (QUANTA 400, USA, 0.5- $30 \mathrm{kV}$ ) and TEM (CM120 Philips, Netherlands). The magnetic properties of CuNi ferrites were investigated using VSM (Cryogenic Limited PPMS, UK) under the applied field of \pm 1 (T). LCR meter (GW INSTEK LCR-8105G, Taiwan) was used to measure dielectric properties at a frequency range of $20 \mathrm{~Hz}-3 \mathrm{MHz}$.

\section{Results and discussion}

\subsection{XRD and FTIR Analyses}

Figure 1-(a, c, and d) shows XRD patterns of the $\mathrm{Ni}_{\mathrm{x}} \mathrm{Cu}_{1-\mathrm{x}} \mathrm{Fe}_{2} \mathrm{O}_{4}$ nanoparticles $(\mathrm{x}=0.0,0.4,1.0)$ calcinated at $200,450,650$, and $850{ }^{\circ} \mathrm{C}$ for $3 \mathrm{~h}$. The XRD patterns for all samples confirmed the appearance of major crystal planes of spinel ferrite at $850{ }^{\circ} \mathrm{C}$. The experimentally calculated values of d-spacing and relative intensities of all reflection peaks were fully compatible with the standard JCPDS Card no (54-0964), (34-0425), and (25-1049) for nickel, copper, and $\mathrm{Ni}-\mathrm{Cu}$ ferrites, respectively. For all the samples prepared and calcinated at different temperatures, it was noticed that when the temperature was increased, the peak of the reflections became sharper. This indicates an improvement in the crystallinity when the calcinating temperature increases. Additionally, it is noticed that as the calcinating temperature increases, the width of the central maxima decreases. This is due to the grain size increase with the increase in the calcinating temperature. The lattice constant $(a)$ was calculated using equations (1) and (2) for cubic and tetragonal structures, respectively [13, 14]:

$$
\begin{aligned}
& a=d \sqrt{h^{2}+k^{2}+l^{2}} \\
& \quad \frac{1}{d^{2}}=\frac{h^{2}+k^{2}}{a^{2}}+\frac{I^{2}}{c^{2}}
\end{aligned}
$$

where $d$ is the interplanar spacing, $h, k$, and $l$ are Miller indices, and $a$ and $c$ are lattice constants. The crystallite size $(D)$ was calculated using the high intensity peak for all the compositions using Scherrer's formula [15]:

$$
D=\frac{K \lambda}{\beta \operatorname{Cos} \theta}
$$

where $\mathrm{k}$ is the shape factor (0.9), $\lambda$ is the wavelength (1.5406 $\AA, \mathrm{CuK} \alpha), \beta$ is the full width at half maximum (FWHM), and $\theta$ is the diffraction angle.

$\mathrm{X}$-ray density $\left(\rho_{\mathrm{x} \text {-ray }}\right)$ and surface area $(S)$ of the ferrite samples were calculated by using the following formulas $[16,17]$ :

$$
\begin{gathered}
\quad \rho_{x-\text { ray }}=\frac{8 M}{N_{A} a^{3}} \\
S=\frac{6}{\rho_{x-\text { ray }} D}
\end{gathered}
$$

where $M$ is the molecular weight of the sample, $N$ is the Avogadro's number, and $a$ is the lattice constant.

The values of the lattice constant, crystallite size, unit cell volume, X-ray density, and surface area of the calcinated samples are summarized in Table-1.

From Table-1, we can observe that x-ray density increases, while surface area decreases, with increasing calcinating temperature. Figure-1 (a) shows XRD patterns of pure $\mathrm{NiFe}_{2} \mathrm{O}_{4}$ nanoparticles that possess sharp characteristic diffraction peaks of (111), (220), (311), (222), (400), (422), (511), (440), and (533) reflection planes at $2 \theta$ values of $18.4^{\circ}, 30.3^{\circ}, 35.7^{\circ}, 37.3^{\circ}, 43.4^{\circ}, 53.9^{\circ}, 57.4^{\circ}, 63.1^{\circ}$, and 
$74.6^{\circ}$, respectively, which can be attributable to face-centered cubic phase (space group $F d \underline{3 m}$ ). An impurity phase of hematite $\left(\alpha-\mathrm{Fe}_{2} \mathrm{O}_{3}\right)$ (JCPDS Card no 025-1402) is observed for the sample Ni-ferrite at $650{ }^{\circ} \mathrm{C}$. The treatment by high-temperature at $850{ }^{\circ} \mathrm{C}$ caused the disappearance of the impurity phase and the formation of a single-phase of Ni-ferrite. Figure-1 (c) shows the XRD profile of the $\mathrm{CuFe}_{2} \mathrm{O}_{4}$ nanoparticles. The peaks that appear at $2 \theta$ range of $18.3^{\circ}, 29.9^{\circ}, 30.5^{\circ}, 34.7^{\circ}, 35.8^{\circ}, 37.1^{\circ}$, $41.8^{\circ}, 43.7^{\circ}, 55.4^{\circ}, 57.8^{\circ}, 62.1^{\circ}, 63.6^{\circ}$, and $74.6^{\circ}$ correspond to the reflection planes (101), (112), (200), (103), (211), (202), (004), (220), (105), (321), (224), (400), and (413), respectively. The XRD shows that the crystal structure was deformed at $650^{\circ} \mathrm{C}$ from the cubic into a tetragonal system, with a secondary phase that belongs to $\mathrm{CuO}$ at 38.7 (JCPDS Card no 48-1548). Figure-1 (e) shows the XRD patterns of the $\mathrm{Ni}_{0.4} \mathrm{Cu}_{0.6} \mathrm{Fe}_{2} \mathrm{O}_{4}$ sample. It was observed that the sample possesses a face-centered cubic structure, with a space group symmetry of Fm3m (JCPDS Card no (25-1049)). The peaks appear at $2 \theta$ range of $18.3^{\circ}, 30.1^{\circ}, 35.5^{\circ}, 37.1^{\circ}, 43.2^{\circ}, 53.6^{\circ}, 57.1^{\circ}, 62.7^{\circ}$, and $74.2^{\circ}$ which correspond to the reflection planes (111), (220), (311), (222), (400), (422), (511), (440), and (533), respectively. It can be noted clearly that the crystalline volume increases with the increase in doping concentration of $\mathrm{Cu}$, which may be due to a larger ionic radius of $\mathrm{Cu}^{2+}(0.73 \AA)$ compared with that of $\mathrm{Ni}^{2+}(0.69 \AA)[18-$ 20]. On the other hand, the crystalline volume increases with increasing calcinating temperature, which is due to crystal growth. Values of the lattice parameter $a$ for $\mathrm{NiFe}_{2} \mathrm{O}_{4}$ and $\mathrm{Cu}_{0.6} \mathrm{Ni}_{0.4} \mathrm{Fe}_{2} \mathrm{O}_{4}$ samples were found to be equal to 8.310 and $8.371 \AA$, respectively. The higher $a$ value for $\mathrm{Cu}_{0.6} \mathrm{Ni}_{0.4} \mathrm{Fe}_{2} \mathrm{O}_{4}$ compared with that of $\mathrm{NiFe}_{2} \mathrm{O}_{4}$ is also due to the larger ionic radius of $\mathrm{Cu}^{2+}$ than that of $\mathrm{Ni}^{2+}$. On the other hand, the lattice constant decreases with increasing calcinating temperature.

Table 1-Average crystalline size, lattice constant, unit cell volume, $\rho_{-}(\mathrm{x}-\mathrm{ray})$, space group, and surface area of $\mathrm{Ni}_{\mathrm{x}} \mathrm{Cu}_{1-\mathrm{x}} \mathrm{Fe}_{2} \mathrm{O}_{4}(\mathrm{x}=0,0.4$, and 1.0) at different temperatures.

\begin{tabular}{|c|c|c|c|c|c|c|c|}
\hline Samples & $\begin{array}{c}\text { Temperatur } \\
\mathrm{e} \\
\left({ }^{\circ} \mathrm{C}\right)\end{array}$ & $\begin{array}{l}\text { Average } \\
\text { crystalline } \\
\text { size }(\mathrm{nm})\end{array}$ & $\begin{array}{c}\text { Lattice } \\
\text { constan } \\
\mathrm{t} \\
(\AA)\end{array}$ & $\begin{array}{l}\text { Unit } \\
\text { cell } \\
\text { volume } \\
(\AA)\end{array}$ & $\begin{array}{l}\rho_{x-\text { ray }} \\
\left(\mathrm{gm} . \mathrm{cm}^{-}\right.\end{array}$ & $\begin{array}{l}\text { Space } \\
\text { Group }\end{array}$ & $\begin{array}{l}\text { Surface } \\
\text { area } \\
\left(\mathrm{m}^{2} \cdot \mathrm{gm}^{-1}\right)\end{array}$ \\
\hline \multirow{4}{*}{$\mathrm{NiFe}_{2} \mathrm{O}_{4}$} & 200 & 27.40 & 8.334 & 578.8 & 5.37 & - & 4.07 \\
\hline & 450 & 34.50 & 8.357 & 583.6 & 5.33 & - & 3.26 \\
\hline & 650 & 38.40 & 8.310 & 573.8 & 5.42 & $\mathrm{Fd} 3 \mathrm{~m}$ & 2.88 \\
\hline & 850 & 38.70 & 8.310 & 573.8 & 5.42 & $\mathrm{Fd} 3 \mathrm{~m}$ & 2.86 \\
\hline \multirow{4}{*}{$\mathrm{Ni}_{0.4} \mathrm{Cu}_{0.6} \mathrm{Fe}_{2} \mathrm{O}_{4}$} & 200 & 25.60 & 8.365 & 585.3 & 5.38 & - & 4.35 \\
\hline & 450 & 29.10 & 8.364 & 585.1 & 5.38 & - & 3.83 \\
\hline & 650 & 33.70 & 8.371 & 586.5 & 5.37 & Fm3m & 3.31 \\
\hline & 850 & 43.00 & 8.371 & 586.5 & 5.37 & Fm3m & 2.59 \\
\hline \multirow{4}{*}{$\mathrm{CuFe}_{2} \mathrm{O}_{4}$} & 200 & 17.90 & 8.359 & 584.0 & 5.44 & - & 6.16 \\
\hline & 450 & 28.50 & 8.310 & 573.8 & 5.53 & - & 3.80 \\
\hline & 650 & 34.00 & 5.830 & 294.3 & 10.76 & $\begin{array}{c}\text { 141 lam } \\
\mathrm{d}\end{array}$ & 1.64 \\
\hline & 850 & 48.00 & 5.830 & 294.3 & 10.76 & $\begin{array}{c}\text { 141\am } \\
\text { d }\end{array}$ & 1.16 \\
\hline
\end{tabular}

Figure-1 (b, d, and f) shows the FTIR spectra of $\mathrm{Ni}_{\mathrm{x}} \mathrm{Cu}_{1-\mathrm{x}} \mathrm{Fe}_{2} \mathrm{O}_{4}(\mathrm{x}=0.0,0.4$ and 1.0) samples at calcinating temperatures of $200,450,650$, and $850{ }^{\circ} \mathrm{C}$ for $3 \mathrm{~h}$. The gels are mostly amorphous (noncrystalline) in nature but can be crystallized by heat treatment [21]. Therefore, when the temperature was raised to $200{ }^{\circ} \mathrm{C}$, the phase beginnings of all samples were shown respectively. On the other hand, as the temperature was increased, we observed a decrease in the intensity of the bands, indicating the disappearance of water molecules and organic groups from the sample. In the case of samples calcinated at $850^{\circ} \mathrm{C}$, we noticed the appearance of two strong absorption bands. One bond was in the high-frequency range $\left(v_{1}\right)$ due to the frequencies of the Fe-O bonds of the tetrahedral (A site) between 557 and $586 \mathrm{~cm}^{-1}$. The other bond was in the low-frequency range $\left(v_{2}\right)$, which is attributed to the frequencies of the M-O bonds of the octahedral (B-site) between 418 and 430) $\mathrm{cm}^{-1}$ [22-25]. 


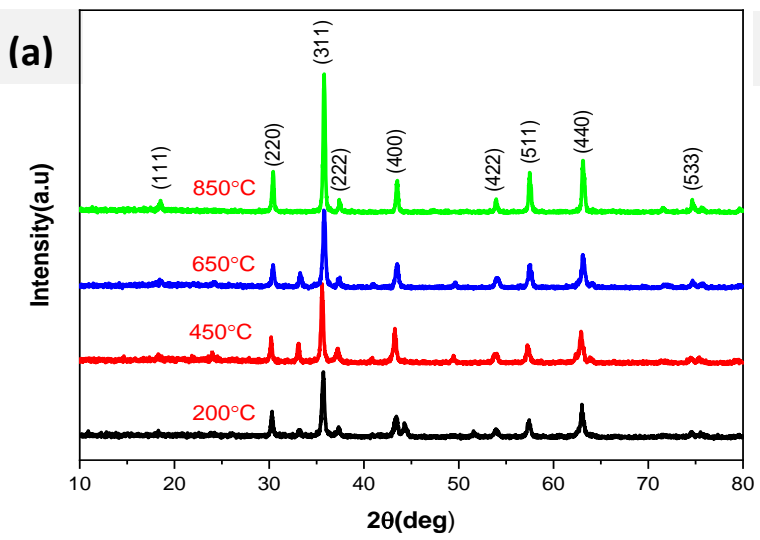

(b
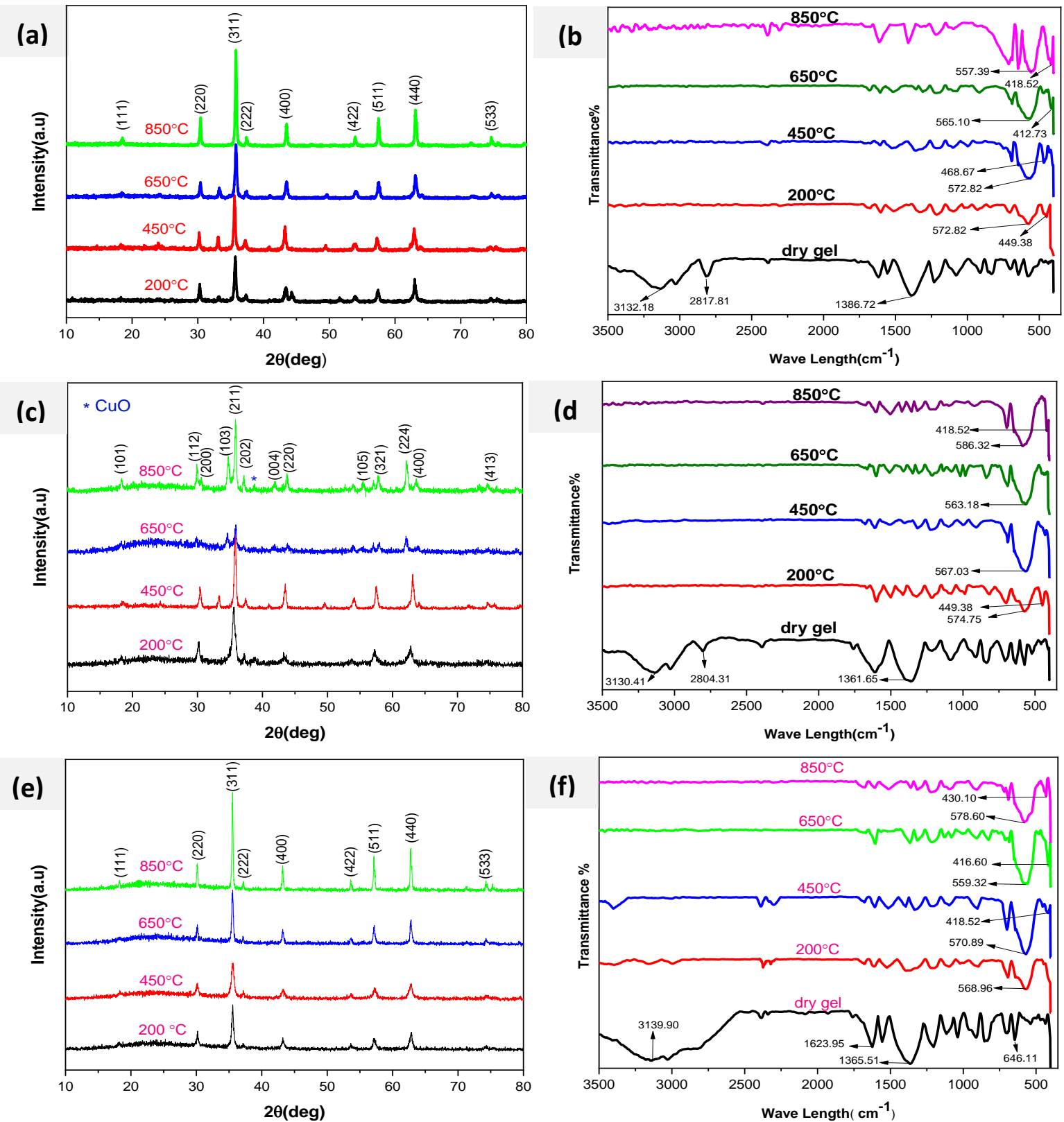

(d

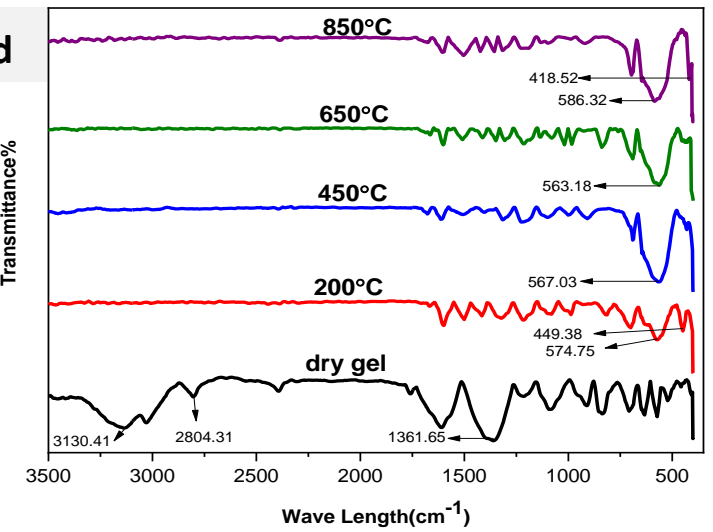

(f)

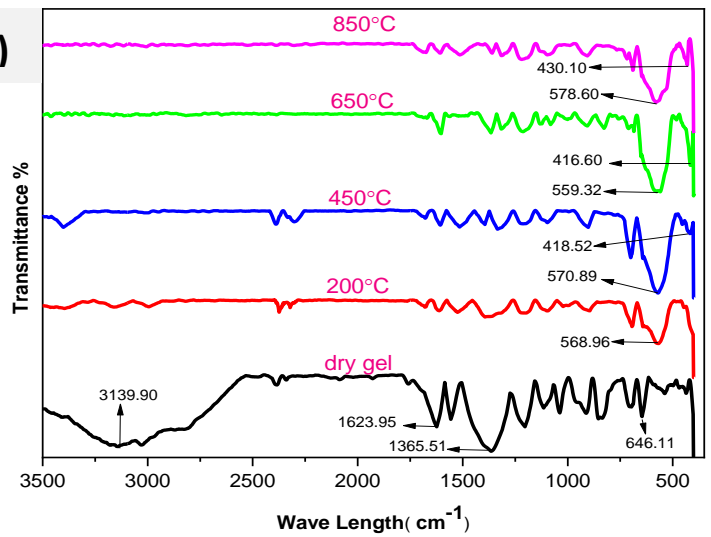

Figure 1 XRD patterns and FTIR spectra of (a)(b) $\mathrm{NiFe}_{2} \mathrm{O}_{4}$, (c) (d) $\mathrm{CuFe}_{2} \mathrm{O}_{4}$, and (e)(f) $\mathrm{Ni}_{0.4} \mathrm{Cu}_{0.6} \mathrm{Fe}_{2} \mathrm{O}_{4}$.

\subsection{SEM and TEM Analysis}

The morphology of the nanoparticles was examined through FE-SEM/EDX and TEM. Figure shows SEM micrographs, the respective energy-dispersive X-ray spectroscopy (EDX), and the particle diameter distribution of $\mathrm{NiFe}_{2} \mathrm{O}_{4}, \mathrm{CuFe}_{2} \mathrm{O}_{4}$, and $\mathrm{Ni}_{0.4} \mathrm{Cu}_{0.6} \mathrm{Fe}_{2} \mathrm{O}_{4}$ nanoparticles calcinated at $850{ }^{\circ} \mathrm{C}$. As can be seen from Figure-2 (a), pristine $\mathrm{NiFe}_{2} \mathrm{O}_{4}$ nanoparticles exhibit polyhedron and spheric morphology, some being accumulated to form larger particles. This agglomeration reduces the surface area of $\mathrm{NiFe}_{2} \mathrm{O}_{4}$ nanoparticles. Figure-2 (b) reveals the diameter histogram for $\mathrm{NiFe}_{2} \mathrm{O}_{4}$ nanoparticles, which displays a homogenous particle size distribution around $35.5 \mathrm{~nm}$ range. Figure-2 (d) shows the SEM micrograph of $\mathrm{CuFe}_{2} \mathrm{O}_{4}$ nanoparticle, revealing a polyhedron shape with few agglomerations and negligible porosity. Figure-2 (e) shows a broad histogram of particle diameter distribution of $\mathrm{CuFe}_{2} \mathrm{O}_{4}$, with average size around $77.7 \mathrm{~nm}$. Figure-2 (g) displays the SEM image of $\mathrm{Cu}$-substituted in $\mathrm{Ni}$ ferrites. The $\mathrm{Ni}_{0.4} \mathrm{Cu}_{0.6} \mathrm{Fe}_{2} \mathrm{O}_{4}$ sample shows uniform grain size distribution with average size around $40.6 \mathrm{~nm}$ (Figure-2(h)). Additionally, the image shows the presence of gaps caused by the release of 
gases during the combustion process, such as $\mathrm{CO}_{2}, \mathrm{H}_{2} \mathrm{O}$, etc. It should be noted now that the average diameter of the $\mathrm{Ni}_{\mathrm{x}} \mathrm{Cu}_{1-\mathrm{x}} \mathrm{Fe}_{2} \mathrm{O}_{4}$ nanoparticles increases with increasing $\mathrm{Cu}^{2+}$ contents from 35.5 to 40.6 and $77.7 \mathrm{~nm}$ for $\mathrm{x}=1.0,0.4$, and 0.0 , respectively. The grain size of all samples was calculated by Image $\mathrm{J}$ software. The chemical composition of the synthesized samples was determined by EDX analysis. Figure- 2 (c) shows the EDX spectrum of $\mathrm{NiFe}_{2} \mathrm{O}_{4}$ compound, which indicated the presence of $\mathrm{Ni}, \mathrm{Fe}$, and $\mathrm{O}$ elements in the sample, where the atomic ratio of $\mathrm{Ni}$ and $\mathrm{Fe}$ was about 1:2. Figure-2 (f) shows the EDX spectrum of $\mathrm{CuFe}_{2} \mathrm{O}_{4}$ compound. We observe the presence of $\mathrm{Cu}, \mathrm{Fe}$, and $\mathrm{O}$ peaks, which are related to the $\mathrm{CuFe}_{2} \mathrm{O}_{4}$ nanoparticles. The $\mathrm{Fe}: \mathrm{Cu}$ ratio was 2:1, which is consistent with theoretical calculations. On the other hand, the EDX spectrum analysis of $\mathrm{Ni}_{0.4} \mathrm{Cu}_{0.6} \mathrm{Fe}_{2} \mathrm{O}_{4}$ compound elements showed spectra for $\mathrm{Cu}, \mathrm{Ni}, \mathrm{Fe}$, and $\mathrm{O}$. All the samples displayed small amounts of the carbon component produced by the organic compound residue.
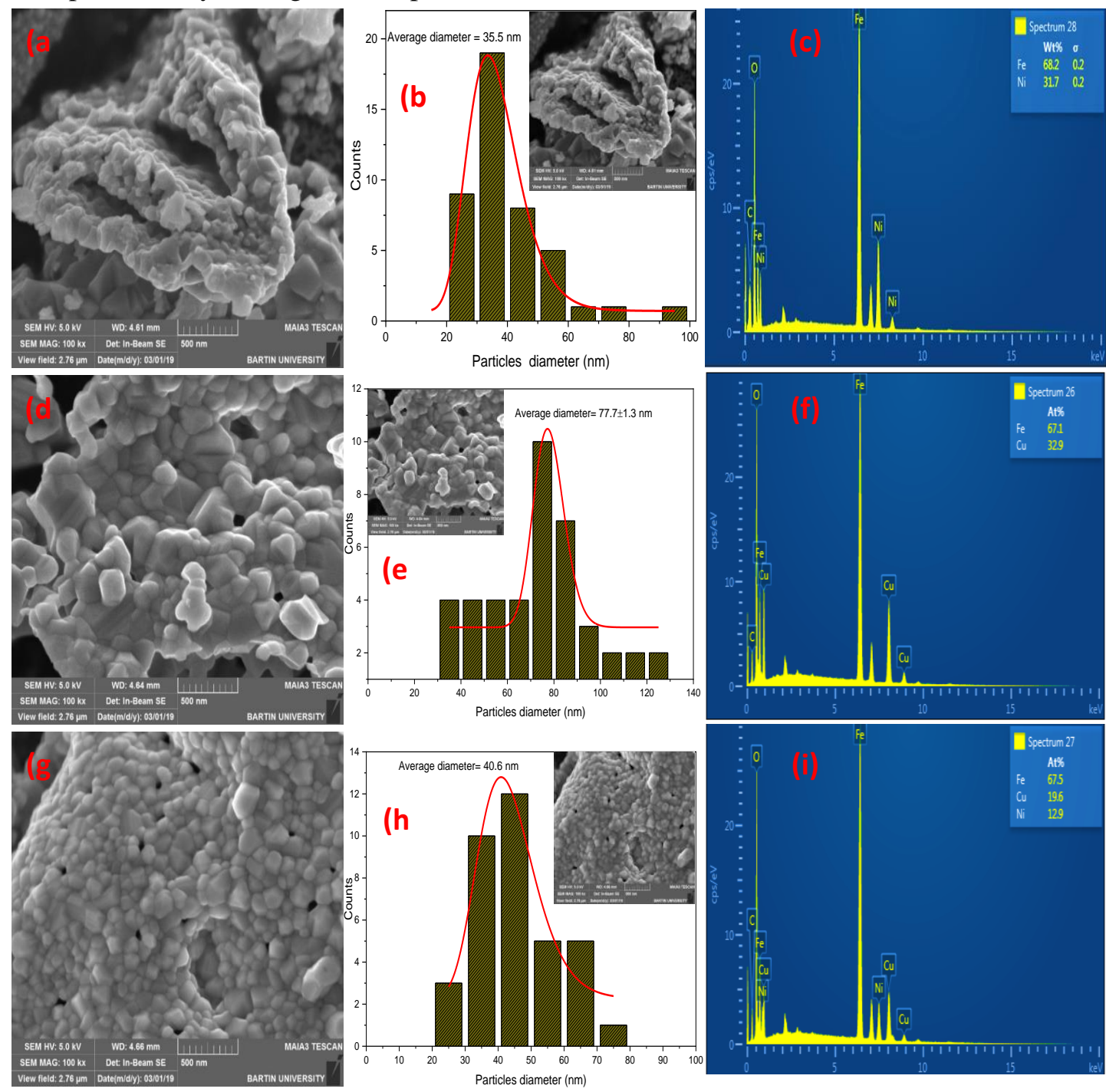

Figure 2-SEM-EDX micrographs and the particles diameter distribution of (a, b, c) pristine $\mathrm{NiFe}_{2} \mathrm{O}_{4}$, (d, e, f) pristine $\mathrm{CuFe}_{2} \mathrm{O}_{4}$, and (g, h, i) $\mathrm{Ni}_{0.4} \mathrm{Cu}_{0.6} \mathrm{Fe}_{2} \mathrm{O}_{4}$.

Figure-3 (a-f) shows TEM morphology images of $\mathrm{NiFe}_{2} \mathrm{O}_{4}, \mathrm{CuFe}_{2} \mathrm{O}_{4}$, and $\mathrm{Ni}_{0.4} \mathrm{Cu}_{0.6} \mathrm{Fe}_{2} \mathrm{O}_{4}$ nanoparticles calcinated at $850{ }^{\circ} \mathrm{C}$. It is observed that most of the particles appear in spherical or polyhedron shapes. This depends on the ratio of $\mathrm{Cu}^{2+}$ cations substitution, where the compound $\mathrm{NiFe}_{2} \mathrm{O}_{4}$ gave more regular form while the compound $\mathrm{Ni}_{0.4} \mathrm{Cu}_{0.6} \mathrm{Fe}_{2} \mathrm{O}_{4}$ showed clear agglomerations. These agglomerations cause an increase in particle size. 

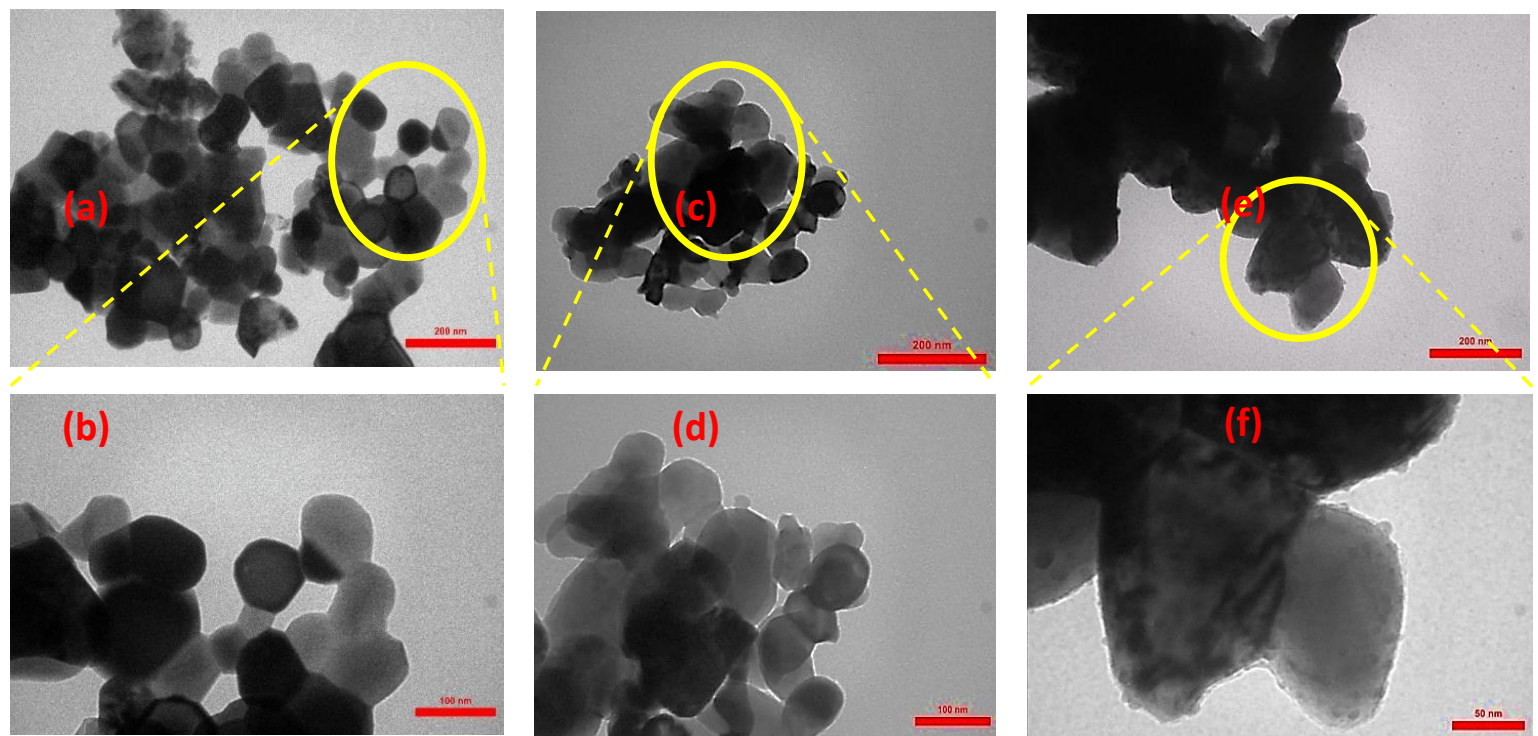

Figure 3 TEM micrographs at different magnifications of $(\mathrm{a}, \mathrm{b})$ pristine $\mathrm{NiFe}_{2} \mathrm{O}_{4},(\mathrm{c}, \mathrm{d})$ pristine $\mathrm{CuFe}_{2} \mathrm{O}_{4}$, and (e, f) $\mathrm{Ni}_{0.4} \mathrm{Cu}_{0.6} \mathrm{Fe}_{2} \mathrm{O}_{4}$.

\subsection{VSM Analysis}

Figure-4 shows the magnetic hysteresis curve of $\mathrm{Ni}_{\mathrm{x}} \mathrm{Cu}_{1-\mathrm{x}} \mathrm{Fe}_{2} \mathrm{O}_{4}(\mathrm{x}=0.0,0.4,1.0)$ calcinated at 850 ${ }^{\circ} \mathrm{C}$. It is observed that all synthesized samples have the behavior of superparamagnetic status. The $M s$ value of the soft ferrite mainly depends upon the net magnetization of the spinel lattice. Magnetic properties of the $\mathrm{Cu}^{2+}$ ions-substituted nickel ferrite depend inherently on cation distribution in the lattice of the ferrites. The magnetic properties, such as $M s, H c$, and $\mathrm{Mr}$ were affected by $\mathrm{Cu}^{2+}$ ion concentration. Magnetic parameters extracted from VSM data at room temperature are summarized in Table-2. The $M s$ value of $\mathrm{NiFe}_{2} \mathrm{O}_{4}$ nanoparticles was 42.25 emu. ${ }^{-1}$, which was high as compared to the value in other samples. While the $M s$ value of $\mathrm{CuFe}_{2} \mathrm{O}_{4}$ nanoparticles was the lowest, being around 32 emu. $\mathrm{g}^{-1}$. This might be due to the presence of $\mathrm{CuO}$ as an impurity, which was in fact detected in $\mathrm{XRD}$ analysis. Additionally, this could be due to the smaller magnetic moment of $\mathrm{Cu}^{2+}$ ion $\left(1.37 \mu_{B}\right)$. However, $\mathrm{CuFe}_{2} \mathrm{O}_{4}$ still has a high saturation magnetization. The experimental magnetic moment per formula unit $\left(\mu_{\mathrm{B}}\right)$ in Bohr magneton was calculated using the following relation [26]:

$$
\mu_{B}=\frac{M M_{S}}{5585}
$$

As related to remnant magnetization, we noticed that the highest value was recorded for $\mathrm{CuFe}_{2} \mathrm{O}_{4}$, followed by $\mathrm{NiFe}_{2} \mathrm{O}_{4}$, and $\mathrm{Cu}_{0.6} \mathrm{Ni}_{0.4} \mathrm{Fe}_{2} \mathrm{O}_{4}$, respectively. Coercivity value was increased with the substitution of $\mathrm{Cu}^{2+}$ ions into $\mathrm{Ni}$-ferrite and the highest value was recorded in $\mathrm{CuFe}_{2} \mathrm{O}_{4}$ due to the potential for a cationic disturbance on the surface [27]. In general, $\mathrm{NiFe}_{2} \mathrm{O}_{4}$ has an inverse spinel structure with $\mathrm{Ni}^{2+}$ ions in octahedral sites, and $\mathrm{Fe}^{3+}$ ions are equally distributed between tetrahedral and octahedral sites [28]. $\mathrm{CuFe}_{2} \mathrm{O}_{4}$ has a partial inverse spinel structure with $85 \%$ of $\mathrm{Cu}^{2+}$ are occupying octahedral sites, while the other $15 \%$ are occupying tetrahedral sites. However, $\mathrm{Fe}^{3+}$ ions are equally distributed in the tetrahedral and octahedral sites [29]. This means that the $\mathrm{Ni}^{2+}$ ions have a strong preference for octahedral sites, while $\mathrm{Cu}^{2+}$ ions have a similar preference for octahedral and tetrahedral sites. When $\mathrm{Cu}^{2+}$ is substituted by $\mathrm{Ni}^{2+}$ in $\mathrm{Ni}_{x} \mathrm{Cu}_{1-x} \mathrm{Fe}_{2} \mathrm{O}_{4}$ nanoparticles, the cation distribution will change and thus changes the magnetic properties subsequently. Table- 2 shows that ferrite samples have various coercivity values. This may be attributed to several reasons, such as composition, surface conditions, and magnetic anisotropy.

The squareness ratio $(S q=M r / M s)$ was increased with increasing the content of $\mathrm{Cu}$. Therefore, the maximum $S q$ value was found to be 0.46 , indicating the enhanced contribution from the cubic anisotropy for $\mathrm{CuFe}_{2} \mathrm{O}_{4}$. Hence, a large coercivity can be expected for $\mathrm{CuFe}_{2} \mathrm{O}_{4}$. The values of anisotropy constant $(K)$ were evaluated using the following relation [30, 31]: 


$$
H_{c}=\frac{0.96 K}{M_{S}}
$$

The anisotropy constant was observed to increase with increasing $\mathrm{Cu}^{2+}$ content.
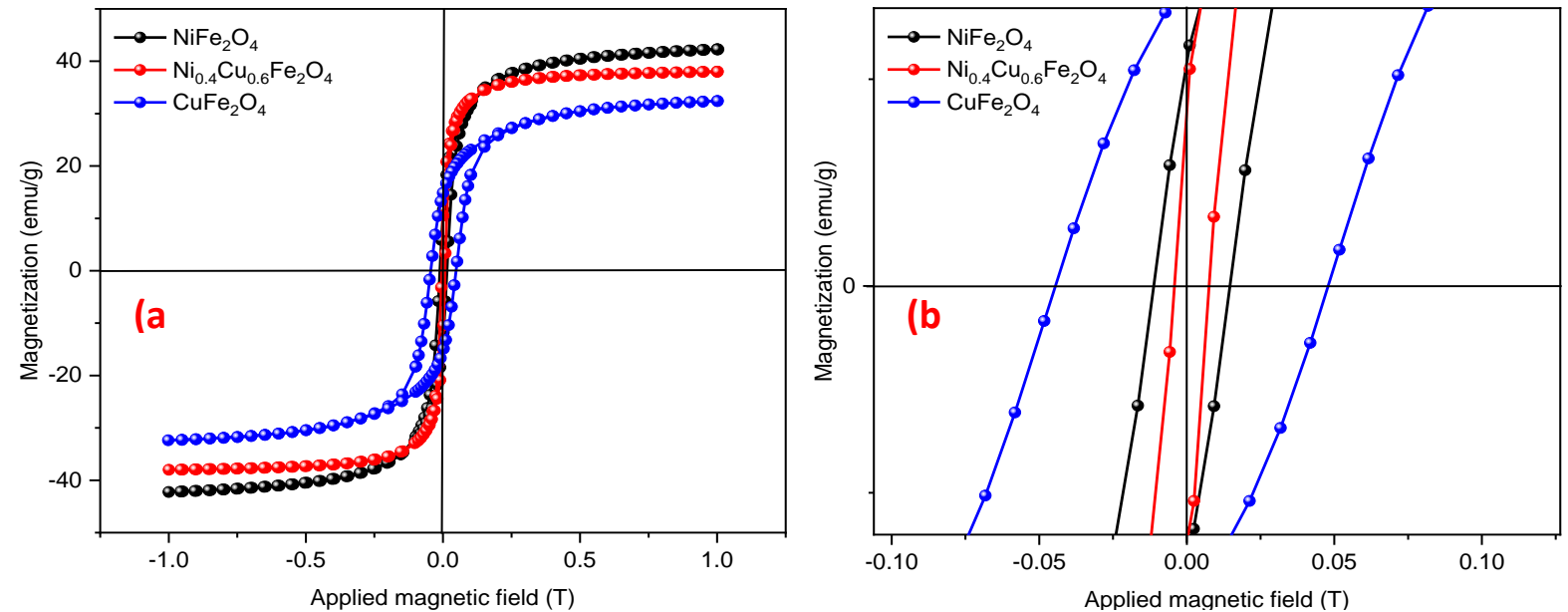

Figure 4-(a) Hysteresis curves of the $\mathrm{NiFe}_{2} \mathrm{O}_{4}, \mathrm{Ni}_{0.4} \mathrm{Cu}_{0.6} \mathrm{Fe}_{2} \mathrm{O}_{4}$, and $\mathrm{CuFe}_{2} \mathrm{O}_{4}$ nanoparticles at room temperature. (b) enlarged view of the $\mathrm{M}-\mathrm{H}$ curve that shows the coercive fields.

Table 2-Saturation magnetization $(M s)$, remanence $(M r)$, coercivity $(H c)$, squareness $(S q)$, magnetic moment $(\mu B)$, and anisotropy constant $(K)$ of $\mathrm{Ni}_{\mathrm{x}} \mathrm{Cu}_{1-\mathrm{x}} \mathrm{Fe}_{2} \mathrm{O}_{4}$ ferrites $(\mathrm{x}=0,0.4,1.0)$ calcinated at 850 ${ }^{\circ} \mathrm{C}$ for $3 \mathrm{~h}$.

\begin{tabular}{|c|c|c|c|c|c|c|}
\hline Sample & $\begin{array}{c}M_{S} \\
\text { [emu. } \mathrm{g}^{-1} \text { ] }\end{array}$ & $\begin{array}{c}M_{r} \\
\text { [emu. } \mathrm{g}^{-1} \text { ] }\end{array}$ & $H_{C}\left[\mathrm{O}_{\mathrm{e}}\right]$ & $S q$ & $\mu_{B}$ & $K \times 10^{-3}\left[{ }_{1}\right.$ emu. $\mathrm{O}_{\mathrm{e}} \mathrm{g}$ \\
\hline $\mathrm{NiFe}_{2} \mathrm{O}_{4}$ & 42.25 & 11.64 & 165.91 & 0.27 & 1.76 & 7.302 \\
\hline $\mathrm{Ni}_{0.4} \mathrm{Cu}_{0.6} \mathrm{Fe}_{2} \mathrm{O}$ & 37.99 & 10.49 & 57.33 & 0.27 & 1.61 & 2.269 \\
\hline $\mathrm{CuFe}_{2} \mathrm{O}_{4}$ & 32.00 & 14.87 & 517.16 & 0.46 & 1.37 & 17.449 \\
\hline
\end{tabular}

\subsection{Dielectric Properties}

AC electrical properties, represented by the real part of dielectric constant $\left(\varepsilon^{\prime}\right)$, the imaginary part of dielectric constant $\left(\varepsilon^{\prime \prime}\right)$ and the loss factor $(\tan \delta)$, in addition to the alternating conductivity $\left(\sigma_{\mathrm{ac}}\right)$ of the samples of $\mathrm{NiFe}_{2} \mathrm{O}_{4}, \mathrm{Ni}_{0.4} \mathrm{Cu}_{0.6} \mathrm{Fe}_{2} \mathrm{O}_{4}$, and $\mathrm{CuFe}_{2} \mathrm{O}_{4}$, were studied as a function of frequency at room temperature in a frequency range of $20 \mathrm{~Hz}-3 \mathrm{MHz}$. The real and imaginary dielectric constant values were calculated by using the following equations [32]

$$
\begin{aligned}
& \varepsilon^{\prime}=\frac{C d}{\varepsilon_{\mathrm{o}} A} \\
& \varepsilon^{\prime \prime}=\varepsilon^{\prime} \tan \delta
\end{aligned}
$$

where $\mathrm{C}$ is the capacitance of the pellet, $\mathrm{d}$ is the thickness, $\mathrm{A}$ is the cross-sectional area, and $\varepsilon_{\mathrm{o}}$ is the permittivity of free space $\left(\varepsilon_{0}=8.854 \times 10^{-12}\right.$ F.m $\left.{ }^{-1}\right)$. Figure-5 (a and b) shows the variation of dielectric constant and imaginary part with frequency. It is seen that the real and imaginary dielectric constant values of the samples decrease with increasing frequency and then they remain constant at high values, which is the normal behavior of most ferrites. The high values of the real dielectric constant at low frequencies are due to the polarization of the space charge due to the large mass of its dipoles compared to other types of polarization (electronic, ionic, and directional). When the frequency is increased, these dipoles cannot rotate with the electric field and thus the dielectric constant decreases. This behavior of ferrite has been observed by many researchers [33-35]. Figure- 4 also shows that the highest value of the real dielectric constant was recorded for $\mathrm{CuFe}_{2} \mathrm{O}_{4}(24304)$ and the lowest value was for $\mathrm{NiFe}_{2} \mathrm{O}_{4}$ (2323), whereas that for $\mathrm{Ni}_{0.4} \mathrm{Cu}_{0.6} \mathrm{Fe}_{2} \mathrm{O}_{4}$ mediated the two values. Since ferrite has a semi-conductive nature, this is affected by doping with other atoms. The effect of doping on charge carriers is either reflected by an increase or a decrease in the real dielectric constant, depending on the type of atom. Therefore, the dielectric constant values differed as a result of the nickel doping process.

The loss factor is a measure of energy dissipation within the dielectric medium and is considered as 
part of the primary loss in the ferrite. We notice from Figure-5 (c) that the maximum values of the loss factor and the loss tangent appeared at low frequencies, while they were decreased with the increase in frequency, until they became constant and stable. Similar results were observed in another research of ferrite systems [36]. This result of the distribution of values in the curve of the imaginary dielectric constant and loss factor is attributed to the Maxwell-Wagner theory of interpolarity [37]. According to this theory, the dielectric constant of ferritic materials consists of two layers, namely the grains and grain boundaries, where the grains are considered regions with low electrical resistance, due to the ideal crystalline properties, while grain boundaries are regions with high resistance. According to Maxwell-Wagner polarization theory, the polarization between surfaces within the grain boundaries occurs due to the accumulation of charge in these high-resistance boundaries. This polarization occurs in all heterogeneous crystalline materials (which are more than one phase). Figure-5 (d) shows the alternating electrical conductivity, as this study provides important information about this process and the effect of deformation on it. In general, the conduction process occurs in the ferrite materials as a result of the transfer of electrons between $\mathrm{Fe}^{+2}$ and $\mathrm{Fe}^{+3}$ located in octagonal locations [38]. The values of $\mathrm{AC}$ conductivity $\left(\sigma_{\mathrm{ac}}\right)$ were calculated using the following equation $[32,39]$ :

$$
\left(\sigma_{\mathrm{ac}}\right)=\omega \varepsilon_{\mathrm{o}} \varepsilon^{\prime} \tan \delta
$$

where $\omega$ is the angular frequency. Figure-5 (d) shows that AC conductivity decreases with the addition of nickel atoms, as electronic transitions between $\mathrm{Fe}^{+2}$ and $\mathrm{Fe}^{+3}$ decrease in the octagonal locations [39]. On the other hand, grain boundaries in the low conduction operate in all samples at frequencies of $10^{3}-10^{4} \mathrm{H}, \mathrm{z}$ where the transmission of electrons between $\mathrm{Fe}^{+2}$ and $\mathrm{Fe}^{+3}$ decreases relatively, while electronic mobility increases in the larger frequencies $\left(10^{4} \mathrm{~Hz}\right)$ as the grain boundaries become more active, which enhances conductivity.
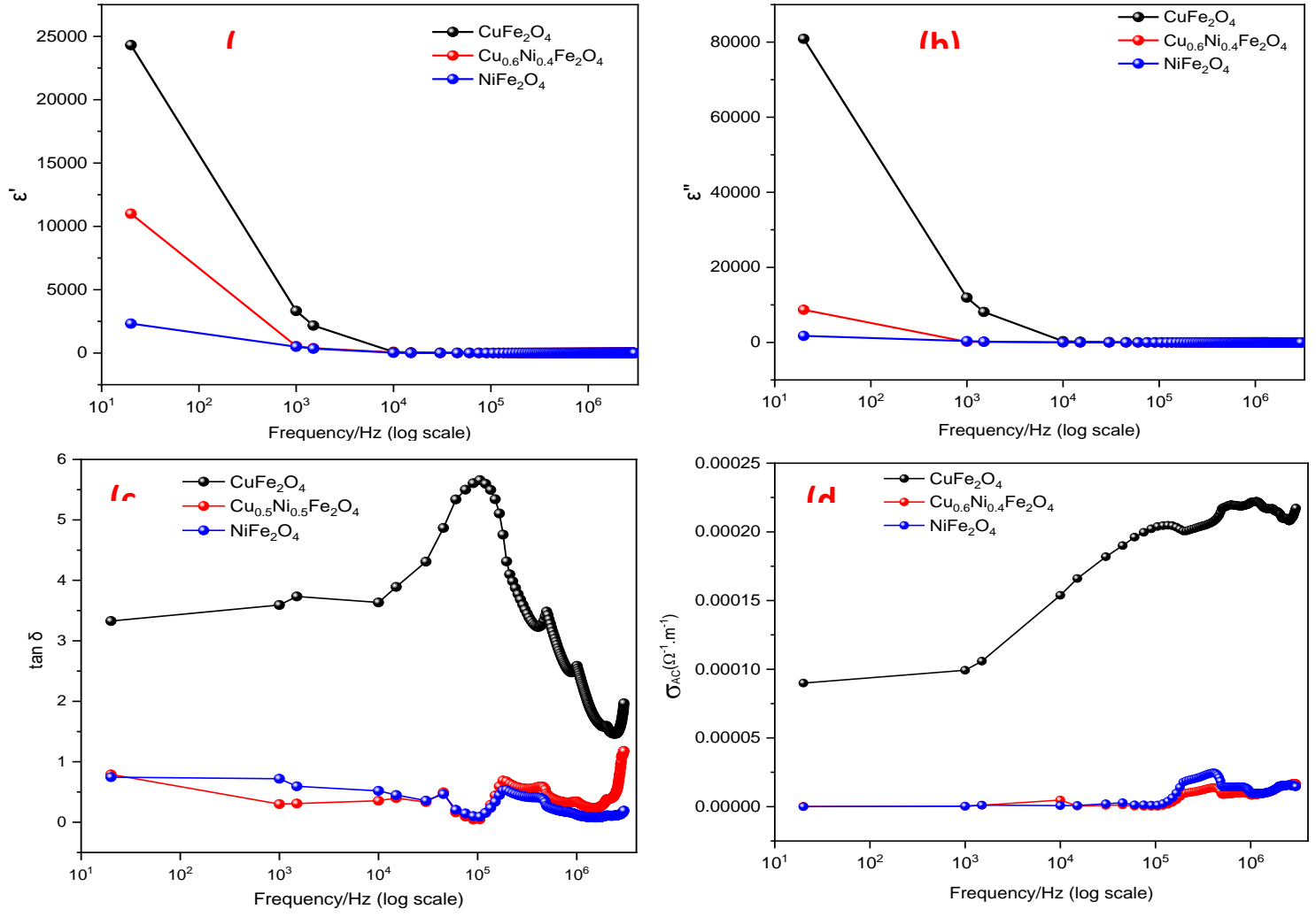

Figure 5 Frequency dependent (a) real part of dielectric constant, (b) imaginary part of dielectric constant, (c) loss factor, and (d) $\mathrm{AC}$ conductivity of $\mathrm{Ni}_{\mathrm{x}} \mathrm{Cu}_{1-\mathrm{x}} \mathrm{Fe}_{2} \mathrm{O}_{4}(\mathrm{x}=0,0.4,1.0)$.

\section{Conclusions}

The $\mathrm{Ni}_{\mathrm{x}} \mathrm{Cu}_{1-\mathrm{x}} \mathrm{Fe}_{2} \mathrm{O}_{4}(\mathrm{x}=0.0,0.4$, and 1.0) nanoparticles were synthesized successfully via the citrate-gel auto combustion method. These $\mathrm{Ni}-\mathrm{Cu}$ ferrite nanoparticles show polyhedron and spherical morphology as revealed via SEM and TEM results. XRD analysis exhibited deformation in system structure, from cubic to tetragonal system, when substituting $\mathrm{Cu}^{2+}$ cations in nickel ferrite completely at $850{ }^{\circ} \mathrm{C}$. The $\mathrm{Cu}$ content has a significant effect on dielectric and magnetic properties, where the 
substitution of copper in nickel ferrite decreases the saturation magnetization and improves dielectric properties of nickel ferrite. Thus, we obtained superb ferrite materials that have mixed properties from $\mathrm{Ni}$-ferrite and $\mathrm{Cu}$-ferrite, which make them good materials for electronic applications, including sensors, EM devices operating at high frequencies, and magnetic fluids.

\section{References}

1. Ramankutty, C.G. and Sugunan, S. A. 2001. Surface properties and catalytic activity of ferrospinels of nickel, cobalt and copper, prepared by soft chemical methods, Applied Catalysis A: General, 218(1-2): 39-51.

2. Zuo, X., Yang, A., Vittoria, C. and Harris, V.G. 2006. computation study of copper ferrite, Journal of applied physics, 99, 0.8M909.

3. Sun, Z., Liu, L., Jia, D. Z. and Pan, W. 2007. simple synthesis of $\mathrm{CuFe}_{2} \mathrm{O}_{4}$ nanoparticles as gassensing materials, Sensors and Actuators B Chemical, 125(1): 144-148.

4. Sun, S., Zeng, H., Robinson, D.B., Raoux ,S., Rice, P.M., Wang, S.X. and Li,G. 2004. Monodisperse $\mathrm{MFe}_{2} \mathrm{O}_{4}(\mathrm{M}=\mathrm{Fe}, \mathrm{Co}, \mathrm{Mn})$ nanoparticles, Journal of the American Chemical Society, 126: 273-279

5. Standley, K.J. 1972. Oxide Magnetic Materials. second Edition. Clarendon Press Oxford.

6. Mazen, S.A. 2000. Tetravalent ions substitution in $\mathrm{Cu}$ - ferrite; structure formation and electrical properties, Materials Chemistry and Physics, 62(2): 131-138.

7. Erb, U. 1995. Electrodeposited nanocrystals: Synthesis, properties and industrial applications, Nanostructured Materials, 6: 533-538.

8. Komarneni, S., D’Arrigo, M.C. Leionelli, C., Pellacani, G.C. and Katsuki, H. 1998. MicrowaveHydrothermal Synthesis of Nanophase Ferrites. Journal of the American Ceramic Society, 81(11): 3041-3043.

9. Sartale, S.D. and Lokhande C.D. 2000. Room temperature preparation of $\mathrm{NiFe} 2 \mathrm{O} 4$ thin films by electrochemical route, Indian Journal of Engineering and Materials Sciences, 7(5): 404-410.

10. Hu, J., Yan, M. and Zhang,W. 2006. Effect of calcination on the magnetic permeability of $\left(\mathrm{Ni}_{0.21} \mathrm{Zn}_{0.58} \mathrm{Cu}_{0.23}\right) \mathrm{Fe}_{1.95} \mathrm{O}_{4}$ ferrite prepared using the sol-gel self-propagated technique, Materials Chemistry and Physics, 98(2-3): 459-462.

11. Sartale, S.D. and Lokhande, C.D. 2001. Electrochemical deposition and oxidation of $\mathrm{CuFe}_{2}$ alloy: a new method to deposit $\mathrm{CuFe}_{2} \mathrm{O}_{4}$ thin films at room temperature. Materials Chemistry and Physics, 70(3): 274-284.

12. Roy, P.K. and Bera, J. 2007. Enhancement of the magnetic properties of $\mathrm{Ni}-\mathrm{Cu}-\mathrm{Zn}$ ferrites with the substitution of a small fraction of lanthanum for iron, Materials research bulletin, 42(1): 7783.

13. Bayrakdar, H., Yalçın, O., Vural, S. and Esmer, K. 2015. Effect of $\mathrm{Cu}$ doped nickel ferrites on structural, magnetic and dielectric properties, Materials Today: Proceedings, 2: 5559 - 5567

14. Kanagaraj M., Sathishkumar P., Selvan G.K., Kokila I.P. and Arumugam S. 2014. Structural and magnetic properties of $\mathrm{CuFe}_{2} \mathrm{O}_{4}$ as-prepared and thermally treated spinel nanoferrites, Indian Journal of Pure \& Applied Physics, 52: 124-130.

15. Rao, P., Godbole, R.V. and Bhagwat, S. 2016. Copper doped nickel ferrite nano-crystalline thin films: A potential gas sensor towards reducing gases, Materials Chemistry and Physics, 171: 260266

16. Naidu, K.Ch. B. and Madhuri,W. 2017. Hydrothermal synthesis of $\mathrm{NiFe}_{2} \mathrm{O}_{4}$ nano-particles: structural, morphological, optical, electrical and magnetic properties, Bulletin of Materials Science, 40: 417-425.

17. Otterstedt, J.-E., Brandreth, D.A. 1998. Small Particles Technology. New York. Plenum Press.

18. Ata-Allah, S.S. and Kaiser, M. 2009. Conductivity and dielectric studies of copper-aluminate substituted spinel nickel ferrite, Journal of Alloys and Compounds, 471(1-2): 303-309.

19. Mazen, S., Abd Allah, M., Nakhla, R.I., Zaki, H.M. and Matawe F. 1993. X-ray analysis and IR absorption spectra of Li-Ge ferrite, Materials Chemistry and Physics, 34(1): 35-40.

20. Amer, M.A., Meaz, T.M., Attalah, S.S.and Ghoneim, A.I. 2014. Structural and magnetic characterization of the $\mathrm{Mg}_{0.2-\mathrm{x}} \mathrm{Sr}_{\mathrm{x}} \mathrm{Mn}_{0.8} \mathrm{Fe}_{2} \mathrm{O}_{4}$ nanoparticles, Journal of magnetism and magnetic materials, 363: 60-65. 
21. Shirsath, S. E., Jadhav, S. S., Mane, M. L., and Li, S. 2016. Ferrites Obtained by Sol-Gel Method. Handbook of Sol-Gel Science and Technology. Cham. Springer.

22. Waldron, R.D. 1955. Infrared spectra of ferrites, Physical Review Journals Archive, 99: 17271735 .

23. Thummer, K.P., Pandya, M.P., Jani, K.H., Modi, K.B.and Joshi, H.H. 2004. Microscope and Macroscopic Magnetice Properties of the $\mathrm{MgAl}_{x} \mathrm{Cr}_{x} \mathrm{Fe}_{2-2 x} \mathrm{O}_{4}$ Spinel Ferrite System, Materials Science, 40(1): 102-112.

24. Guo, L., Shen, X., Meng, X., Feng, Y. 2010. Effect of Sm3+ ions doping on structure and magnetic properties of nanocrystalline $\mathrm{NiFe}_{2} \mathrm{O}_{4}$ fibers, Journal of Alloys and Compounds, 490(1): 301-306.

25. Nakamoto, K. 2006. Infrared and Raman spectra of inorganic and coordination compounds. Handbook of Vibrational Spectroscopy. John Wiley \& Sons, Ltd.

26. Manju B.G. and Raj, P. 2019. Green Synthesis of Nickel-Copper Mixed Ferrite Nanoparticles: Structural, Optical, Magnetic, Electrochemical and Antibacterial Studies, Journal of Electronic Materials, 48(12): 7710-7720

27. Rais, A., Taibi, K., Addou, A., Zanoun, A. and Al-Douri,Y. 2014. Copper Substitu-tion Effect on the Structural Properties of Nickel Ferrites, Ceramics International, 40: 14413-14419.

28. Perron, H., Mellier, T., Domain, C., Roques, J., Simoni, E., Drot, R. and Catalette, H. 2007. Structural investigation and electronic properties of the nickel ferrite $\mathrm{NiFe}_{2} \mathrm{O}_{4}$ : A periodic density functional theory approach, J. Phys.: Condens. Matter, 19: 1-10.

29. Zuo, X., Yang, A., Vittoria, C., and Harris, V. G. 2006. Computational study of copper ferrite $\left(\mathrm{CuFe}_{2} \mathrm{O}_{4}\right)$, J. Appl. Phys., 99(8): 1-3.

30. Yadav R. S., Kuřitka, I., Jarmila, V., Havlica, J., Masilko, J., Kalina, L., Tkacz, J., Švec, J., Enev V. and Hajdúchová, M. 2017. impact of grain size and structural changes on magnetic, dielectric, electrical, impedance and modulus spectroscopic characteristics of $\mathrm{CoFe} 2 \mathrm{O} 4$ nanoparticles synthesized by honey mediated sol-gel combustion method, Advances in Natural Sciences: Nanoscience and Nanotechnology, 8(4): 1-14.

31. Stoner, E.C. and Wohlfarth, E.P. 1948. A mechanism of magnetic hystersis in hetrogeneous alloys, Philos Trans R Soc London Ser A 240: 599. Reprinted by IEEE Trans Magn 27: 3475 (1991).

32. Anjum, S., Rashid, A., Bashir, F., Pervaiz, M. and Zia, R. 2015. Effect of $\mathrm{Cu}$ Doped Nickel Ferrites on Structural, Magnetic and Dielectric Properties, Materials Today: Proceedings, 2(10): 5559-5567.

33. Kumar, A. and Yadav, K.L. 2011. Magnetic, magnetocapacitance and dielectric properties of $\mathrm{Cr}$ doped bismuth ferrite nanoceramics, Materials Science and Engineering, 176(3): 227-230.

34. Malik, H., Khan, M. A., Hussain, A., Warsi, M. F., Mahmood, A., and Ramay, S. M. 2018. Structural, spectral, thermal and dielectric properties of $\mathrm{Nd}-\mathrm{Ni}$ co-doped $\mathrm{Sr}-\mathrm{Ba}-\mathrm{Cu}$ hexagonal ferrites synthesized via sol-gel auto-combustion route. Ceramics International, 44(1): 605-612.

35. Omri, A., Dhahri, E., Costa, B.F.O., and Valente, M.A. 2020. Structural, Electric and Dielectric properties of $\mathrm{Ni}_{0.5} \mathrm{Zn}_{0.5} \mathrm{FeCoO}_{4}$ ferrite prepared by sol-gel, Journal of Magnetism and Magnetic Materials, 499: 1-28.

36. Wang, Y., Zhu, J., Zhang, L., Yang, X. and Wang, X. 2006. Preparation and characterization of perovskite $\mathrm{LaFeO}_{3}$ nanocrystals, Materials Letters, 60(13-14): 1767-1770.

37. Thomas, N., Jithin, P. V., Sudheesh, V. D. and Sebastian, V. 2017. Magnetic and dielectric properties of magnesium substituted cobalt ferrite samples synthesized via one step calcination free solution combustion method, Ceramics International, 43(9): 7305-7310.

38. Farea, A.M.M., Khalid, Sh.K., Batoo, M., Yousef, A., GyuLee, Ch. and Alimuddin, R. 2009. Influence of the doping of $\mathrm{Ti}^{4+}$ ions on electrical and magnetic properties of $\mathrm{Mn}_{1+\mathrm{x}} \mathrm{Fe}_{2-2 \mathrm{x}} \mathrm{Ti}_{\mathrm{x}} \mathrm{O}_{4}$ ferrite, Journal of Alloys and Compounds, 469(1-2): 451-457.

39. Dahham, N. A., Abdul-Aziz, Ab. F. and Jasim A. S. K. 2017. Fabrication And Studies Of structural, Dielectrical Properties Of $\left(\mathrm{Ni}_{0.95-\mathrm{x}} \mathrm{Co}_{\mathrm{x}} \mathrm{Cu}_{0.05} \mathrm{Fe}_{2} \mathrm{O}_{4}\right)$ Composites by Powder Technology Method, Tikrit Journal of Pure Science, 22(11): 48-54. 